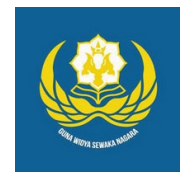

Jurnal Analogi Hukum

Journal Homepage: https://ejournal.warmadewa.ac.id/index.php/analogihukum

\title{
Peranan Hakim untuk Mendamaikan Para Pihak yang Bersengketa dalam Perkara Perdata di Pengadilan Negeri Denpasar
}

\author{
Made Rai Diascitta Hardi Sentana*, I Wayan Wesna Astara dan I Nyoman Gede Sugiartha
}

Fakultas Hukum, Universitas Warmadewa, Denpasar-Bali, Indonesia

*hardisentana@gmail.com

\begin{abstract}
How To Cite:
Sentana, M. R. D. H., Astara, I. W. W., \& Sugiartha, I. N. G. (2020). Peranan Hakim untuk Mendamaikan Para Pihak yang Bersengketa dalam Perkara Perdata di Pengadilan Negeri Denpasar. Jurnal Analogi Hukum. 2(2). 203-208. Doi: https://doi.org/10.22225/ ah.2.2.1933.203-208
\end{abstract}

\begin{abstract}
The peace agreement between the two parties on a voluntary basis for mutual yield or relinquish a portion of its rights to prevent things. This research aims to know two things, namely, first, to know the role of judges in reconciling the parties in a civil lawsuit and the second, to know the power of the law ruling in the case of civil peace. This research was carried out at the Denpasar District Court by using method of empirical research and purposive technique. Analysis of the data of this research was done qualitatively. Based on the results of the interviews with District Court Judges Denpasar, Denpasar District Court, the Registrar and the lawyers (Advocates) then this research it can be concluded that the first, judges have the role and obligation to reconcile the parties in dispute before it is exposed to the Court of session and the form of the verdict of peace is a peace act having the force of law as the verdict.
\end{abstract}

Keywords: Peace, Justice, Civil Litigation

\begin{abstract}
Abstrak-Perdamaian merupakan persetujuan antara kedua belah pihak secara sukarela untuk saling mengalah atau melepaskan sebagian dari haknya untuk mencegah timbulnya perkara. Penelitian ini bertujuan untuk mengetahui dua hal, yaitu pertama, untuk mengetahui peran hakim dalam mendamaikan para pihak dalam perkara perdata dan yang kedua, untuk mengetahui kekuatan hukum putusan perdamaian dalam perkara perdata. Penelitian ini dilaksanakan di Pengadilan Negeri Denpasar dengan menggunakan metode penelitian empiris dan teknik purposive. Analisis data penelitian ini dilakukan secara kualitatif. Berdasarkan hasil wawancara dengan Hakim Pengadilan Negeri Denpasar, Panitera Pengadilan Negeri Denpasar, dan Pengacara (Advokat) maka penelitian ini dapat disimpulkan bahwa pertama, Hakim memiliki peran dan kewajiban untuk mendamaikan para pihak yang bersengketa sebelum dihadapkan pada sidang pengadilan dan bentuk dari putusan perdamaian adalah berupa akta perdamaian yang memiliki kekuatan hukum seperti putusan biasa.
\end{abstract}

Kata Kunci: Perdamaian, Hakim, Perkara Perdata

\section{Pendahuluan}

Sesuai dengan kodratnya, manusia disamping sebagai mahluk individu juga merupakan mahluk sosial, maka dalam keberadaannya manusia merupakan kesatuan yang bulat yang harus dikembangkan secara seimbang, selaras dan serasi. Bertitik tolak pada sifat kodrat manusia tersebut, maka manusia baru akan mempunyai arti, apabila ia berbaur dengan kehidupan bermasyarakat. Dengan hidup bermasyarakat manusia akan dapat mempertahankan hidupnya atau berusaha mengejar kehidupan yang lebih baik demi kesejahteraan hidupnya dan hal ini ditandai dengan timbulnya bermacam-macam kebutuhan atau kepentingan-kepentingan diantara anggota masyarakat itu sendiri. Perlu di kemukakan di sini bahwa yang dimaksud dengan kepentingankepentingan adalah perbuatan hukum yang menimbulkan hak-hak keperdataan (Iskandar, 1981).

Meskipun sudah ada peraturan, baik itu peraturan tertulis maupun peraturan yang tidak tertulis, mengatur tingkah laku manusia dalam 
hidup bermasyarakat, atau sudah ada pedoman bagi warga masyarakat tentang bagaimana selayaknya orang berbuat atau tidak berbuat di dalam hidup bermasyarakat, menjalani hidupnya di dalam masyarakat yang berkenaan dengan aturan-aturan hukum masih saja ada manusia yang melanggar aturan-aturan tersebut.

Dalam hal terjadinya perselisihan atau sengketa Perdata salah satu upayanya adalah jalan perdamaian. Hasil dari pada penyelesaian dengan perdamaian dapat dikatakan sangat luhur, karena antara para pihak yang bersengketa sama-sama menang atau yang disebut dengan win-win solution, dengan mengesampingkan diri dari sifat egoistic dan serakah, mau menang sendiri, dengan demikian, tidak ada yang menang atau bukan winning or losing seperti penyelesaian melalui putusan pengadilan (Harahap, 2005).

Walaupun perkaranya sudah diajukan kepengadilan Negeri ini tidak berarti tidak menutup kemungkinan bagi pihak-pihak untuk memilih penyelesaian secara damai, bahkan kesempatan itu pun masih tetap terbuka bagi para pihak untuk mengadakan perdamaian karena Hakim yang memeriksa perkara tersebut wajib mengupayakan perdamaian kepada para pihak yang bersengketa sesuai dengan ketentuan Peraturan Mahkamah Agung Nomor 1 Tahun 2016 pasal 3 ayat (1). Hakim yang dimaksud adalah hakim pada Pengadilan tingkat pertama dalam lingkungan peradilan umum dan peradilan agama. Hakim pemeriksa perkara merupakan majelis hakim yang dipilih oleh ketua Pengadilan guna memeriksa dan mengadili perkara.

Perdamaian di dalam persidangan perdata dilakukan dengan mediasi yaitu penyelesaian sengketa melalui proses perundingan untuk memperoleh kesepakatan Para Pihak dengan dibantu oleh Mediator. Mediator merupakan Hakim atau pihak lain yang memiliki Sertifikat Mediator sebagai pihak yang tidak memihak guna membantu para pihak dalam proses perundingan untuk mencari berbagai cara penyelesaian sengketa tanpa harus dengan menggunakan cara memutus atau memaksakan sebuah penyelesaian.

Dengan adanya suatu kepastian hukum tersebut sudah barang tentu akan timbul juga berbagai aspek hukum serta permasalahanpermasalahan di dalam prakteknya. Masalahmasalah yang timbul dalam praktek akan sangat sulit diatasi, kalau tidak diadakan penelitian. Terutama untuk memperoleh data-data yang menyangkut permasalahan-permasalahan perdamaian di dalam sidang dan tinjauannya juga tidak akan terlepas dari segi sosiologis, yuridis serta hal-hal yang menyangkut dengan tujuan dari perdamaian di dalam sidang. Pada penelitian sebelumnya, (Ningrumi, Asmaraputra \& Martana, 2012) mengungkapkan proses penyelesaian sengketa melalui perdamaian yang dibantu oleh pihak ketiga sebagai penengah yang bersifat netral. Mediasi mengacu pada Peraturan Mahkamah Agung Nomor 01 Tahun 2008 tentang Prosedur Mediasi di Pengadilan Negeri Denpasar. Walaupun dalam prakteknya keberhasilan suatu proses mediasi ditentukan oleh profesionalitas seorang mediator, namun demikian, kepentingan para pihak juga sangat menentukan tingkat keberhasilannya

Berdasarkan atas latar belakang yang diuraikan diatas, maka penilitian ini dilakukan untuk menganalisis peran serta kewajibankewajiban hakim dalam mendamaikan para pihak yang bersengketa dalam perkara perdata di persidangan dan kekuatan hukum putusan perdamaian yang dilakukan di depan sidang pengadilan.

\section{Metode}

Sebagaimana yang telah di uraikan diatas, maka metode penelitian yang digunakan pada penelitian ini, adalah jenis penelitian hukum empiris yaitu mengenai sejauh mana teori hukum dapat diterapkan di dalam suatu masyarakat tertentu dan apakah aturan-aturan hukum tertentu dipatuhi oleh pemegang peran dalam hidup bermasyarakat (Marzuki, 2016)

Pendekatan masalah yang digunakan dengan memadukan antara peraturan perundang -undangan yang berlaku dengan kenyataankenyataan yang ada di masyarakat/ pengadilan.

Sumber data yang digunakan dalam penelitian ini bersumber pada: Data Primer, yaitu sumber data yang didapatkan langsung dari objek penelitian lapangan (field research) dengan wawancara dan study dokumen. Wawancara dilakukan dengan hakim di Pengadilan Negeri Denpasar dan studi dokumen yaitu mencari kasus yang terjadi dan pernah disidangkan serta di putus oleh Pengadilan Negeri Denpasar.

Data Sekunder, yaitu sumber data yang di peroleh dari penelitian kepustakaan. Yang diperoleh dari literatur-literatur dan peraturan perundang-undangan yang berkaitan dengan permasalahan yang diangkat, antara lain: Undang-undang Dasar 1945, Kitab Undangundang Hukum Acara Perdata, Peraturan Mahkamah Agung Nomor 1 Tahun 2016, Kitab 
Undang-undang Hukum Perdata.

\section{Hasil dan Pembahasan}

\section{Peranan Hakim dalam Mendamaikan Para Pihak Dalam Perkara Perdata}

Hakim merupakan pejabat peradilan Negara yang diberi wewenang oleh undangundang untuk mengadili, sedangkan istilah hakim artinya orang yang mengadili perkara dalam pengadilan. Kekuasaan kehakiman adalah kekuasaan Negara yang merdeka untuk melaksanakan peradilan untuk menegakkan hukum dan keadilan berdasarkan Pancasila demi terciptanya Negara Hukum Republik Indonesia, sesuai dengan ketentuan pasal 24 Undang-undang Dasar Negara Republik Indonesia tahun 1945.

Hakim dalam melaksanakan pemeriksaan perkara di persidangan Pengadilan Negeri, diberi kewajiban menawarkan perdamaian kepada para pihak yang berperkara. Dalam kaitannya ini hakim diwajibkan dapat memberikan suatu pengertian bahwa perdamaian adalah salah satu cara penyelesaian yang lebih bagus dan lebih bijaksana dari pada melalui putusan pengadilan, baik dari pandangan hukum dimasyarakat maupun dilihat pada segi waktu, biaya, dan tenaga yang diperlukan (Syahrani, 2000)

Menurut ketentuan Peraturan Mahkamah Agung Nomor 1 Tahun 2016 pasal 3 (3) Apabila Hakim Pemeriksa Perkara tidak menyarankan dilakukannya mediasi kepada para pihak sehingga para pihak akhirnya tidak melaksanakan mediasi maka Hakim Pemeriksa Perkara tersebut dinyatakan melanggar perundang-undangan mengenai Mediasi Di Pengadilan dan Mahkamah Agung dengan putusan sela akan memerintahkan Pengadilan Tingkat Pertama untuk melakukan proses mediasi. Waktu yang diberikan adalah 30 hari terhitung pada saat diperolehnya pemberitahuan putusan sela Pengadilan Tinggi atau Mahkamah Agung. Hasil mediasi dan berkas perkara disampaikan oleh Ketua Pengadilan Tingkat I ke Pengadilan Tinggi atau Mahkamah Agung yang kemudian akan diputus oleh Mahkamah Agung atau pengadilan Tinggi.

Para pihak baik penggugat maupun tergugat akan dijelaskan tentang Prosedur Mediasi oleh Hakim Pemeriksa Perkara yang berisikan:

a. Pengertian dan Manfaat mediasi, hal ini bertujuan agar para pihak baik tergugat maupun penggugat sadar akan pentingnya perdamaian dan apa saja keuntungan yang didapatkan apabila baik pihak penggugat maupun tergugat mau menempuh jalur perdamaian atau mediasi.

b. Kewajiban agar para pihak menghadiri langsung proses mediasi, serta memberitahukan apa akibat apabila para pihak atau salah satu pihak tidak beriktikad baik dalam jalannya proses mediasi. Akibat dari para pihak yang tidak beriktikad baik pada saat proses mediasi berlangsung adalah membayar biaya mediasi baik itu pihak tergugat maupun penggugat.

c. Biaya karena menggunakan Mediator non hakim atau bukan pegawai pengadilan karena penggunaan mediator hakim atau pegawai pengadilan tidak dikenakan biaya.

d. Apabila para pihak setuju atau sepakat melakukan perjanjian atau mediasi di persidangan maka hasil dari mediasi di persidangan tersebut akan di kukuhkan dengan akta perdamaian dan kewajiban para pihak untuk menandatangani formulir penjelasan mediasi.

Setelah memberikan pemaparan tentang kewajiban melaksanakan mediasi Hakim Pemeriksa Perkara mewajibkan para pihak untuk menempuh mediasi hari itu juga untuk memilih mediator dengan batas waktu selama dua (2) hari. Hakim yang bertindak sebagai mediator harus berada ditengah-tengah para pihak yang bersengketa ataupun didalamnya, tidak boleh terpengaruh dari kondisi internal maupun eksternal, Mediator tidak berperan sebagai hakim, ia bukan hakim yang memutuskan siapa yang benar dan salah, bukan juga bertindak sebagai penasehat hukum, tetapi berperan sebagai penolong. (Sumardjono, 2008)

Hakim pemeriksa perkara akan menangguhkan proses persidangan guna memberikan waktu untuk para pihak melakukan perdamaian. Jangka waktu untuk para pihak baik pihak tergugat maupu penggugat melakukan mediasi adalah 30 (tiga puluh) hari terhitung pada saat melakukan Mediasi oleh Hakim Pemeriksa Perkara. Apabila waktu yang diberikan tidak mencukupi maka akan diberikan jangka waktu tambahan yaitu paling lama 30 (tiga puluh) hari terhitung sejak jangka waktu Mediasi yang di perintahkan oleh Hakim Pemeriksa Perkara berakhir dan para pihak harus memohonkan permintaan tambahan waktu kepada Hakim Pemeriksa Perkara dengan menjelaskan alasan mengapa dibutuhkan perpanjangan waktu tersebut. 
Mediator hakim ataupun pegawai pengadilan yang ditunjuk sebagai mediator dapat menentukan waktu dilaksanakannya mediasi, setelah mendapatkan penetapan penunjukan mediator oleh Hakim Pemeriksa Perkara. Mediator Hakim ataupun pegawai pengadilan yang telah ditunjuk dapat menggunakan gedung Pengadilan dan tidak dikenakan biaya untuk itu kepada para pihak. Pemanggilan para pihak oleh mediator dimintai bantuan kepada juru sita atau juru sita pengganti.

Mediasi yang berhasil mencapai kesepakatan antara para pihak dibantu oleh mediator, yang kemudian dirumuskan secara tertulis dalam Kesepakatan Perdamaian yang ditanda tangani oleh Para Pihak dan Mediator. Pada saat merumuskan Kesepakatan Perdamaian mediator hakim maupun pegawai pengadilan yang ditunjuk/ dipilih harus memastikan agar kesepakatan tersebut tidak bertentangan dengan hukum, ketertiban umum dan kesusilaan, serta tidak merugikan pihak ketiga. Para pihak yang diwakili oleh kuasa hukumnya harus memberikan pernyataan tertulis bahwa pihak tersebut telah setuju atas perjanjian yang telah dicapai. Mediator akan mengajukan Kesepakatan Perdamaian kepada Hakim Pemeriksa Perkara yang kemudian dikukuhkan dalam Akta Perdamaian.

Setelah menerima Kesepakatan Perdamaian yang syarat dan ketentuanya telah terpenuhi, Hakim Pemeriksa Perkara menetapkan waktu sidang untuk membacakan Akta Perdamaian. Dimana para pihak diwajibkan untuk mematuhi dan melaksanakan isi dari putusan perdamaian yang telah mereka sepakati yang telah dikukuhkan atau dikuatkan dalam Akta Perdamaian. Tetapi apabila mediasi gagal maka tugas mediator untuk melaporkannya secara tertulis kepada Hakim Pemeriksa Perkara (Harahap, 2008).

Hal ini diperjelas dalam pasal 131 ayat 1 HIR yang menyatakan "Jika para pihak telah datang menghadap tetapi tidak dapat dilaksanakan perdamaian (hal mana harus dicantumkan dalam berita acara persidangan), dibacakan surat-surat yang telah diajukan oleh para pihak.

Dalam HIR dan R.Bg. tidak ada ketegasan mengenai sampai kapan batas waktunya Hakim dapat mengusahakan perdamaian. Peraturan tidak mengikat suatu batas waktu pada tercapainya suatu perdamaian, sehingga setiap saat selama proses berjalan perdamaian dapat diadakan.
Ini berarti bahwa hakim dalam pemeriksaan perkara di Pengadilan Negeri mempunyai kesempatan yang luas untuk menawarkan perdamaian kepada para pihak yang berperkara dan bukan saja pada awal sidang tetapi juga pada setiap sidang, sampai pada akhirnya sebelum Hakim menjatuhkan putusan. Dalam HIR dan R.Bg. tidak ada ketegasan mengenai sampai kapan batas waktunya Hakim dapat mengusahakan perdamaian. Peraturan tidak mengikat suatu batas waktu pada tercapainya suatu perdamaian, sehingga setiap saat selama proses berjalan perdamaian dapat diadakan.

Ini berarti bahwa hakim dalam pemeriksaan perkara di Pengadilan Negeri mempunyai kesempatan yang luas untuk menawarkan perdamaian kepada para pihak yang berperkara dan bukan saja permulaan sidang tetapi juga pada setiap sidang, sampai pada akhirnya sebelum Hakim menjatuhkan putusan.

Semua cara yang ditempuh atau diusahakan oleh Hakim tersebut diharapkan akan menumbuhkan pengertian, kesadaran dan keinginan pihak-pihak yang bersengketa untuk mengakhiri sengketa secara perdamaian, sekalipun mungkin hati mereka tertutup atau tidak ada niat untuk mengadakan perdamaian.

Apabila dengan berbagai cara telah ditempuh oleh Hakim dalam usaha mendamaikan para pihak ternyata tidak ada hasilnya, maka untuk menghindari jangan sampai penyelesaian perkara berlarut-larut Hakim harus menghentikan usahanya untuk sementara waktu untuk mendamaikan para pihak.

Usaha hakim dalam mengusahakan perdamaian tidak akan selalu berujung dengan keberhasilan apabila tidak adanya kesadaran dari para pihak bersengketa yang ingin menyelesaikan perkaranya secara damai, karena dapat atau tidaknya perdamaian itu tercapai tergantung pada kebijaksanaan Hakim dan kesadaran serta keinginan para pihak yang bersengketa.

\section{Kekuatan Hukum Putusan Perdamaian Dalam Perkara Perdata}

Adapun akibat hukum dari putusan perdamaian yang telah tercapai dalam persidangan Pengadilan Negeri ketentuan di dalam HIR dan R.Bg diatur dalam pasal-pasal sebagai berikut:

Pasal 130 (2) HIR dan 154 (2) R.Bg. 
menyebutkan bahwa:

Jika dapat dicapai perdamaian sedemikian, maka dibuatlah untuk itu suatu akta dalam sidang tersebut dan kedua belah pihak dihukum untuk menaati isi dari perjanjian yang telah dibuat itu, akta itu mempunyai kekuatan yang sama dan dilakukan dengan cara yang sama sebagai suatu putusan yang biasa (Iskandar, 1981)

Pasal 130 (3) HIR dan 154 (3) R.Bg menyebutkan bahwa:

Terhadap suatu keputusan tetap oleh Hakim tidak dapat dilakukannya banding ataupun kasasi.

Putusan perdamaian mempunyai kekuatan mengikat terutama pada pihak-pihak yang mengadakan perdamaian dimana mereka sebelumnya telah sepakat atau mengadakan perjanjian untuk mengakhiri perselisihan atau persengketaannya dengan cara perdamaian. Kesepakatan atau persetujuan itu mereka rumuskan secara terperinci dan diangkat sebagai isi perdamaian, atas dasar isi perdamaian yang mereka buat tersebut kemudian hakim membuatkan akta perdamaian.

Dengan didasarkan atas kesepakatan atau persetujuan dari pihak-pihak dalam putusan perdamaian ini berarti bahwa:

Secara moral, mereka harus jujur patuh dan konsekuen terhadap apa yang mereka buatkan, apa yang mereka ucapkan dan perbuat untuk melaksanakan isi perdamaian secara sukarela.

Secara yuridis, terhadap mereka yang tidak mematuhi isi perdamaian, akan diberlakukan ketentuan hukum dan salah satu pihak yang dirugikan dapat memohon bantuan Ketua Pengadilan Negeri yang bersangkutan guna memberikan teguran kepada pihak yang telah lalai dalam mematuhi isi akta perdamaian yang telah mereka sepakati. Apabila pihak yang telah lalai ini tidak mau secara sukarela memenuhi kewajiban hukumnya, maka untuk selanjutnya Pengadilan Negeri akan menjalankan putusan perdamaian secara paksa.

Ketentuan yang mengatur akibat hukum bagi pihak-pihak yang lalai memenuhi kewajibannya sebagaimana yang tercantum di dalam putusan perdamaian, ini berarti bahwa putusan perdamaian mempunyai arti eksekutorial atau mempunyai daya wujud untuk dilaksanakan. Sebagaimana yang dikatakan oleh Soepomo, yang menyatakan bahwa Putusan Hakim memiliki kekuatan eksekutorial (kekuatan memaksa) yang artinya apa yang ditentukan dalam putusan itu dapat dijalankan dengan paksaan alat Negara (Soepomo, 1981).

\section{Simpulan}

Hakim mempunyai peranan dan kewajiban untuk mendamaikan para pihak yang bersengketa sebelum dihadapkan pada sidang pengadilan sesuai dengan ketentuan pasal 130 HIR dan pasal 154 R.Bg. Hakim sebagai mediator dalam penyelesaian sengketa di dalam persidangan diatur dalam Peraturan Mahkamah Agung Nomor 1 Tahun 2016 tentang Proses Mediasi di Pengadilan, apabila para pihak tidak berhasil didamaikan barulah hakim akan melanjutkan pada proses persidangan, dan apabila hakim dapat mendamaikan para pihak, maka hakim membuat putusan perdamaian yang mempunyai kekuatan hukum tetap.

Kekuatan Hukum dari Putusan Perdamaian sama dengan putusan biasanya dimana Putusan Perdamaian mempunyai kekuatan mengikat para pihak yang mengadakan perdamaian dimana sebelumnya mereka telah sepakat untuk mengakhiri sengketanya dengan cara perdamaian sesuai dengan ketentuan pasal 130 (2) HIR dan pasal 154 (2) R.Bg. Apabila ada salah satu pihak yang melanggar isi dari putusan perdamaian maka pihak yang merasa dirugikan dapat meminta Ketua Hakim Pengadilan Negeri untuk memaksa pihak yang melanggar isi dari putusan perdamaian, secara paksa menjalankan putusan perdamaian.

Mengingat putusan perdamaian mempunyai kekuatan hukum yang sama dengan kekuatan putusan yang telah memiliki kekuatan hukum tetap maka para pihak hendaknya lebih serius mengupayakan perdamaian dengan berbagai keuntungan seperti menghilangkan rasa dendam di dalam hati yang timbul akibat adanya perselisihan sehingga tidak menimbulkan konflik yang berkepanjangan serta hubungan para pihak sebagai sesama warga masyarakat akan rukun kembali. Juga menghimbau kepada para penegak hukum agar lebih siap mental dan meningkatkan disiplin pada diri sendiri dalam mengembangkan dan menjalankan tugasnya jangan sampai mudah tergoyah dan tergiur oleh materi demi suksesnya keadilan.

\section{Daftar Pustaka}

Harahap, K. (2008). Hukum Acara Perdata. Bandung: PT Grafiti Budi Utami

Harahap, M. Y. (2005). Hukum Acara Perdata. Jakarta: Sinar Grafika 
Kitab Undang-Undang Hukum Perdata

Kitab Undang-Undang Hukum Acara Perdata

Marzuki, P. M. (2016). Penelitian Hukum. Jakarta: Kencana Prenamedia Group

Ningrumi, I. G. A. D., Asmaraputra, D. N. R., \& Martana, N. A. (2012). Penyelesaian Sengketa Melalui Mediasi Oleh Para Pihak Di Pengadilan Negeri Denpasar Dalam Perkara Perdata. Kertha Wicara : Journal Ilmu Hukum, 1(01). Retrieved from https://ojs.unud.ac.id/index.php/ kerthawicara/article/view/4332

Oeripkartawinata, I. (1981). Perdamaian dalam Perkara Perdata, Pro Yustitia.

Peraturan Mahkamah No. 1 Tahun 2016 Tentang Prosedur Mediasi di Pengadilan

Sumardjono, M. S. W. (2008). Mediasi Sengketa Tanah. Jakarta: Kompas

Syahrani, H. R. (2000). Materi Dasar Hukum Acara Perdata. Bandung: PT Citra Aditya Bakti

Soepomo. (1981) Hukum Acara Perdata Pengadilan Negeri. Pradnya Paramita

Undang Undang Negara Republik Indonesia (UUD NRI) Tahun 1945 Amandemen ke-4 